Em relação aos amores, Knibiehler encontra uma tradição também negativa, do cristianismo ao marxismo, em que se valoriza muito mais o esforço coletivo do que os prazeres individuais. No empenho de refrear a sexualidade, os ocidentais criaram abismos entre o amor carnal e o espiritual, estigmatizando os prazeres com o pecado e a culpa. Hoje, ao contrário, denunciase a "tirania do prazer", mas aumenta a mercantilização do corpo e "a tristeza do sexo". O que quer dizer amar, então?, pergunta ela.

É, portanto, na conclusão que a autora explicita brevemente suas propostas "utópicas", contribuindo para a criação de um projeto de educação dos jovens voltada para a sexualidade e para a vida. Sua perspectiva é a defesa do modelo republicano, do ideal de cidadania e da luta pelos direitos democráticos, reatualizando, porém, seus modos de procedimento. Nesse sentido, ganha espaço a idéia de investir nos ritos de passagem, especialmente naqueles promovidos pela escola, tão importantes na vida dos jovens, associando a educação sexual à educação cívica: "Esses ritos ajudariam os jovens a construir sua identidade sexuada e ultrapassar as etapas que levam à idade adulta" (p. 248). Ao contrário dos eventos que estimulam a competitividade e humilham publicamente, a autora defende aqueles que permitem restaurar uma formação humanista sexuada, tendo o Estado como um educador e civilizador.

É de se perguntar, contudo, se os investimentos que Knibiehler defende seriam viáveis na "sociedade de controle", tal como a define Deleuze, em que as instituições agonizam e em que, como quer Foucault, trata-se de lutar não apenas contra o Estado, mas contra as formas de subjetivação impostas aos indivíduos. Refletindo com os/as anarquistas, cujas críticas à sociedade disciplinar e cujas experiências e concepções da sexualidade anteciparam em quase um século a Revolução sexual dos anos 60 , a criação de novas formas de subjetividade, a partir de redes de solidariedade e de amizade pública, demandam a formulação de éticas libertárias, de novos imaginários sociais mais do que a reutilização de espaços simbólicos obsoletos, instituídos pelo Estado, que, em nome da democracia, reforça modos excludentes e hierarquizadores de organização da vida social. Ao invés de renovar os internatos, como sugere a autora, deveríamos ajudar a libertar os jovens, tanto quanto os adultos, de todos os tipos de prisão e dos símbolos que os justificam e consolidam como necessários.

MARGARETH RAGO

Universidade Estadual de Campinas

\title{
Quando eu é uma outra
}

\section{Jacques e Lotka: uma história da Resistência.'}

YUNG DE PRÉVAUX, Aude.

Rio de Janeiro: Editora Record, 2003. $252 \mathrm{p}$.

Um dos mais clássicos recursos narrativos dos folhetins, sejam eles jornalísticos, sejam eletrônicos, é o da identidade encoberta: por exemplo, uma personagem acredita-se filha biológica de um casal; porém, este, na verdade, apenas a criou. Um belo dia, ela descobre, de modo súbito e impactante, sua efetiva origem, emocionando fortemente os espectadores/ leitores...
Não só através desses folhetins, mas também das seções policiais, tais episódios se fazem presentes na mídia com freqüência, com alguns temperos tecnológicos contemporâneos, como os exames de DNA, feitos a partir da saliva deixada pela pessoa em uma guimba, e de fotos de crianças desaparecidas nos monitores de computador, em um caso de crianças seqüestradas de maternidades e criadas como filhas pela própria seqüestradora, fartamente estampado no noticiário.

Raramente, todavia, produzem uma pequena obra-prima, como Jacques e Lotka, muito além da literatura de massa e do consumo descartável.

Eis a história: Aude, a autora do livro, estava com 23 anos, quando soube, abrupta e casualmente, quem, de fato, ela era.

Na Biblioteca Nacional, em Paris, Aude 
passava horas, então, diariamente, decifrando montanhas de documentos empoeirados, para sua pesquisa sobre um assunto tão remoto - e tão próximo, como Freud bem poderia explicar como o dualismo cátaro, de questões identitárias. Um dia, um estranho aproximou-se dela. Vendoa assinar uma ficha de requisição de obras, interpelou-a: não seria ela, acaso, a filha do almirante Trolley de Prévaux?

Sem dar-lhe tempo de se refazer do choque de representar-se sendo uma outra, estranha a si mesma, o desconhecido resumiu-lhe a história, até ali desconhecida: Aude era, sim, a filha sobrevivente de um casal de heróis da Resistência, mortos pelos nazistas, quando ela era ainda um bebê.

A mãe, judia de origem polonesa, nascida em Nova York, chamava-se Charlotte Leitner - e o pai, de família francesa burguesa e católica, era o almirante Jacques de Prévaux...

Esse encontro absolutamente inesperado mudaria, definitivamente, a vida de Aude: para ela, passou a valer a fórmula de Rimbaud segundo a qual "eu é um outro" -, transformada, depois, por Philippe Lejeune em título de livro sobre a autobiografia, da literatura à mídia.

Criada como filha por um de seus tios paternos, já falecido na época da revelação, e por sua esposa, Aude interpelou essa tia, que lhe deu, então, as primeiras pistas do quebra-cabeça identitário que ela mesma montaria, na escrita de seu livro.

Na demanda de sua identidade e da história da vida de seus pais e de seus primeiros meses de idade, a autora reconstrói todo um momento histórico da Europa, da Primeira até a Segunda Guerra Mundial, transcendendo, em muito, a simples reconstituição da história do casal - de seus pais biológicos - que, praticamente, ela não chegara a conhecer.

Entrevistas, cartas, fotos, documentos militares, diários, malas de guardados de seu pai são algumas das fontes primárias de sua magnífica narrativa. Nela se entrecruzam diversos gêneros discursivos: biografia, romance histórico, relato de guerra, espionagem e contraespionagem...

Jornalista, correspondente do Libération, em Genebra, Aude escreve agora para várias publicações francófonas e, casada com um britânico, mãe de um filho, reside, atualmente, em Munique.

Recebeu, com o livro, os prêmios SaintSimon e Maréchal Foch, da Academia Francesa.

Entre dois mundos - como no dualismo cátaro da pesquisa sobre os hereges albigenses e seu maniqueísmo -, o do seu passado tranqüilo, monocultural, solidamente francês e o do presente que lhe é jogado nos braços, revolto, cosmopolita e multicultural, Aude indaga-se: quem sou? Quem foram meus pais? Quais destes rostos, entre milhares de fotos antigas, são os deles?

Se optou pelo jornalismo, escrevendo magníficas reportagens investigativas - como bem poderia ter sido esse livro -, Aude não renunciou, está claro, à pesquisadora que trazia em si, mas, simplesmente, redirecionou-a

De certa forma, como os cátaros que pesquisava quando the foi revelada sua identidade, seus pais biológicos foram, senão propriamente hereges, certamente nada ortodoxos para os padrões comportamentais hegemônicos em seu tempo.

Jacques, o normando, filho de bucaneiros, experimentou, entre muitas outras coisas, o ópio e a boemia, divorciando-se da primeira esposa para casar-se com a amante judia, que tivera um passado lésbico, tudo isso ainda nas primeiras décadas do século $X X$, quando a revolução no comportamento ainda aguardava os anos 60 para romper as amarras e explodir.

Fruto de um casamento misto, malvisto pelas leis raciais então vigentes, Aude não apenas reconstituiu, como paciente detetive que fosse também autor de romances policiais e histórias de amor, a narrativa da vida e da morte de seus pais, mas também recuperou um dos lados de sua genealogia, sua ascendência materna, mergulhada em sombras e silêncios pelos que a criaram.

A leitores de um século como o XXI, já marcado, desde os primeiros momentos, pela guerra e pelo terror, o romance de dois heróis da Resistência Francesa, tal como narrado por sua filha sobrevivente, saberá interessar e emocionar profundamente.

Muito além de uma história de família, e de uma história da Resistência Francesa, Jacques e Lotka é uma narrativa das transformações por que passou a representação da mulher, no século XX, e, conseqüentemente, do amor e do casamento.

Filha de judeus da Europa Central que emigraram da Polônia para Nova York, em busca de melhores dias, Lotka nasceu e cresceu nos Estados Unidos, na atmosfera barulhenta e agitada do East Side, onde fez a aprendizagem de uma sociedade multicultural, atravessada por diversas comunidades de imigrantes.

Essa sociedade urbana, industrial, globalizada e trepidante, com suas gangues e bairros miseráveis, foi, todavia, demais para a família Leitner . 
Ela regressou para Jaroslaw, na Polônia. A linhagem feminina - a mãe, Bertha, a avó, Rosa Stieglitz - era famosa, lá, pelo talento e pela energia com que essas mulheres assumiam as rédas da economia familiar, Bertha como modista e Rosa como parteira.

Indo todos os anos às capitais da moda de então, Viena e Paris, Bertha trazia para sua clientela, ávida de novidades, sempre a mais recente tendência fashion. Foi ela quem instou a filha Lotka a ir para Paris, conseguindo-lhe um estágio em uma famosa modista francesa da Avenue Montignon. Aí começaria tudo, na vida da jovem judia imigrante que se tornaria modelo, descobriria Claudel e Péguy, viveria um amor lésbico e, casando-se com Prévaux, desempenharia missões perigosas na Resistência
Francesa, até sua morte.

Rompendo limites de classe social, religião e cultura, aí incluídos os dos papéis tradicionais de gênero, a história da resistência de Jaques e Lotka, tal como reconstituída e narrada por sua única filha, Aude Yung-de Prévaux, que um dia abriu as malas ancestrais sobre o tapete $e$ encarou o enigma das fotos antigas, dos velhos papéis em busca de uma resposta à pergunta "quem sou?", emociona e seduz a todos nós.

1 Tradução de Un amour dans la tempête de l'histoire: Jacques et Lotka.

Maria Consuelo Cunha Campos Universidade do Estado do Rio de Janeiro

\section{Mulheres, raça e cristianismo popular no Brasil}

\author{
Blessed Anastácia: Women, \\ Race, and Popular Christianity in \\ Brazil.
}

BURDICK, John.

New York/London: Routledge, 1998. $246 \mathrm{p}$.

Começo esta resenha pelo fim: ao terminar a leitura desse livro, perguntei-me se o movimento negro no Brasil já o descobriu. Creio ser urgente sua tradução, tanto pelo peso acadêmico de sua contribuição - conteúdo (discussão teórica e política dos movimentos sociais) e metodologia como por sua contribuição a discussões específicas dos movimentos negros em nosso país. O autor não teme a explicitação de sua posição de "pesquisador engajado": Ele quer, com esse estudo, contribuir para 0 desenvolvimento da identidade de seu interlocutor principal, o movimento negro brasileiro, bem como de suas táticas e objetivos. John Burdick, professor de Antropologia na Syracuse University, USA, já é conhecido entre nós por uma obra anterior. ${ }^{1}$ Agora, o autor volta ao tema da religião popular e nos oferece um excelente trabalho antropológico em que questões de raça, gênero, religião e cultura popular mesclam-se, tendo como inspiração, por assim dizer, a figura da escrava negra torturada e tornada 'santa' por suas/seus fiéis devotos. No correr do livro, Burdick vai mostrando o que significa, para ele, fazer um estudo antropológico, explicitando na conclusão várias questões fundamentais à metodologia dessa tarefa.

Logo na introdução, fica claro que, para o autor o livro não é sobre Anastácia em si, mas sobre o racismo e sua expressão através da religião. Sensibilizado pela crueldade e injustiça da opressão devida à cor da pele no Brasil, diz que "a questão não é mais se a cor de um/a brasileiro/a influencia suas chances de vida, mas como o faz" (p. 1). Ao trabalhar o problema central da pesquisa - o significado político da cultura popular -, leva em conta a religião como um elemento inalienável dessa cultura em nosso país e, especialmente, o Cristianismo, por sua disseminação e sua força social e política. Como lembra o autor a maioria das pessoas que se identificam como negras ou pretas são praticantes de alguma forma de Cristianismo.

O campo empírico analisado é o Pentecostalismo, a devoção à escrava Anastácia, a Missa católica afro. As entrevistadas são majoritariamente mulheres. Discutindo com ativistas do movimento negro, e diferentemente delas/es, o autor considera o Cristianismo "um idioma viável para imaginar e articular identidade étnica negra e anti-racismo" (p. 21). Atento à complexidade das questões que aborda, Burdick evita simplificações e tenta apanhar as 